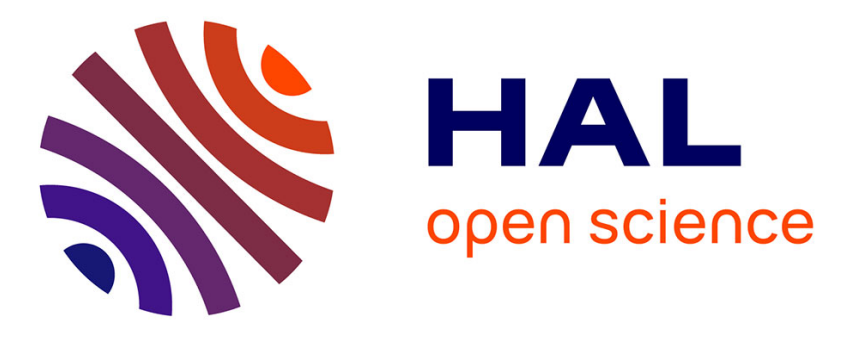

\title{
Anomalures (Rodentia, Anomaluridae) in central Gabon: species composition, population densities and ecology
}

Catherine Julliot, Simona Cajani, Annie Gautier-Hion

\section{- To cite this version:}

Catherine Julliot, Simona Cajani, Annie Gautier-Hion. Anomalures (Rodentia, Anomaluridae) in central Gabon: species composition, population densities and ecology. Mammalia, 1998, 62 (1), pp.921. 10.1515/mamm.1998.62.1.9. hal-01320856

\section{HAL Id: hal-01320856 https://hal.science/hal-01320856}

Submitted on 23 Nov 2017

HAL is a multi-disciplinary open access archive for the deposit and dissemination of scientific research documents, whether they are published or not. The documents may come from teaching and research institutions in France or abroad, or from public or private research centers.
L'archive ouverte pluridisciplinaire HAL, est destinée au dépôt et à la diffusion de documents scientifiques de niveau recherche, publiés ou non, émanant des établissements d'enseignement et de recherche français ou étrangers, des laboratoires publics ou privés. 


\title{
Anomalures (Rodentia, Anomaluridae) in Central Gabon : species composition, population densities and ecology
}

\author{
by C. JULLIOT ${ }^{1}$, S. CAJANI ${ }^{2}$, and A. GAUTIER-HION ${ }^{2}$ \\ 'URA 1183, CNRS - MNHN. 4. ar. du Petit-Château. 91800 Brunờ, France \\ 'UMR 6552. CNRS - Univ. de Rennes I. Station biologique, 35380 Paimpont, France
}

\begin{abstract}
Summary. - A population survey of anomalures in the Forêt des Abeilles, Central Gabon, was undertaken by exploring hollow trees over 75 ha. Three species were identified: Anomalurus derbianus, A. pusillus, and Idiurus macrotis. Population estimates indicate that a total of about 500 anomalures could be present per $\mathrm{km}^{2}$. The three species shelter in hollow trees during the day and have a strictly nocturnal activity. Den selection depends mainly on the size and configuration of the cavity; neither tree species nor tree diameter are important. Data on home ranges and nightly movements were obtained by the radio-tracking of two A.derbianus and one I. macrotis. In dens, A. derbianus (about $700 \mathrm{~g}$ body weight) were mostly found either alone or in pairs of one female and a young. During the nocturnal activity period, two to three individuals (always including a young) were seen together on several occasions. Communal nesting occurred in 1 . macrotis (about $30 \mathrm{~g}$ body weight) with groups ranging from two to 40 individuals. By contrast. they were always observed alone during the night activity period. Few feeding data were recorded : all involved the consumption of phloem sap after scratching the bark of a small number of tree species. Great quantities of leaves and insects (ants and termites) were found in a stomach of A. derbianus. Comparisons with results obtained from long term studies on gliders in Australasia highlight several convergence points between African flying squirrels and flying phalangers (Phalangeridae), in particular when comparing species with similar body weights. Our data confirm that anomalures occupy the niche of gliders on the African continent.
\end{abstract}

Résumié. - Une étude du peuplement d'anomalures en Forêt des Abeilles, au Gabon, a été entreprise notamment en explorant les arbres creux sur une surface de 75 ha. Trois espèces ont été identifiées (Anomalurus derbiamus, A. pusillus, et Idiurus macrotis) dont la densité totale pourrait atteindre 500 individus par $\mathrm{km}^{2}$. Les trois espèces s'abritent le jour dans des arbres creux et ont un rythme d'activité strictement nocturne. La sélection des gîtes s'opère sur la taille et la configuration des cavités tandis que ni l'espèce végétale, ni la taille des arbres ne semblent des critères de choix. La forte densité d'arbres creux, notamment chez l'espèce dominante de la forêt, Paraberlinia bifoliolata, laisse penser que la disponibilité en gîtes n'est pas un facteur limitant des populations. Des données préliminaires sur les domaines vitaux et les déplacements nocturnes ont été obtenues par le marquage et le suivi par radio-pistage de deux A. derbianus et un I. macrotis. Dans les gîtes, les A. derbiamus sont observés seuls, ou groupés par deux (femelle et jeune), voire trois individus. Durant la période d'activité, il n'est pas rare d'observer jusqu'à trois individus ensemble. En l'absence de données sur les systèmes d'accouplement, il n'est pas possible de trancher entre un type de vie essentiellement solitaire ou familial. Au contraire, les

Mammalia. t. 62, $n^{\circ} 1,1998: 9-21$. 
I. macrotis, toujours observés seuls pendant les périodes d'activité, ont une occupation communautaire des gîtes qui peuvent abriter plus de 40 individus. Les rares données directes d'observation sur les régimes concernent des animaux consommant la sève du phloème de quelques espèces d'arbres, après en avoir gratté l'écorce. Des quantités importantes de feuilles et d'insectes (fourmis et termites) ont été trouvées dans un estomac d'A. derbianus.

La comparaison de nos résultats avec ceux concernant les Phalangeridae d'Australie fait apparaître de nombreuses convergences, notamment lorsque l'on compare les animaux de poids équivalent. Les anomalures occupent bien en Afrique la niche des "planeurs » d'Australie.

\section{INTRODUCTION}

The anomalures are often referred to as African flying squirrels. The family Anomaluridae includes three genera (Anomalurus, Idiurus and Zenkerella) and seven species which inhabit the tropical and subtropical forests of western and central Africa (Dieterlen 1993). Most information about the biology and ecology of anomalures is anecdotal or drawn from observations of captive animals. Some species are nocturnal and shelter in hollow trees during the day (A.derbianus and Idiurus species). whereas others should be more diurnal and build nests made of leaves ( $A$. beecrofti). Bark, leaves, and flowers appear to constitute the bulk of their diets (Rahm 1960, 1966. 1969 ; Rahm and Christiansen 1963; Rosevear 1969: Jones 1971, reviewed in Kingdon 1974). Little is known about $A$. pusillus or Z. insignis.

In this study, we present data on a community of anomalures living in Central Gabon, give estimates of population densities and social groupings based on the study of their dens, and provide the first quantitative data on the activity patterns and the use of space by two species, A. derbianus and I. macrotis.

\section{METHODS}

\section{The study site}

The study site (La Makandé ; $0^{\circ} 40^{\circ} 39^{\prime \prime} \mathrm{S}, 11^{\circ} 54^{\circ} 35^{\prime \prime} \mathrm{E}$ ) is located in the "Forêt des Abeilles ", Central Gabon. The habitat consists of tropical rain forest, dominated by Caesalpiniaceae and Burseraceae with two dominant tree species : Paraberlinia bifoliolata (Caesalpiniaceae) and Aucoumea klaineana (Burseraceae; Doucet 1996). The forest is uninhabited and was selectively logged in June-August 1992 at a rate of 1.7 tree/ha (mainly A. klaineana, $>70 \mathrm{~cm}$ dbh; Lassere and Gautier-Hion 1995). It has not sustained any other human activity since. The climate is tropical with two dry seasons and two rainy seasons. The mean annual rainfall (from July 1993 to July 1996) was $1762 \mathrm{~mm}$.

\section{Data collection}

The study was conducted during two periods of three months from August to October 1995, and from December 1995 to February 1996. First, we searched for animals at night $(1900 \mathrm{~h}$ to $2300 \mathrm{~h})$ using a portable $12 \mathrm{~V}$ spotlight. Second, surveys of hollow potential den trees were performed on 75 ha during both study periods. The 
location of each hollow tree was mapped and the number, size, and height of entrance holes were recorded. Three classes of tree diameters were considered: small $(30 \mathrm{~cm}<\mathrm{dbh}<50 \mathrm{~cm})$; medium $(50 \mathrm{~cm}<\mathrm{dbh}<70 \mathrm{~cm})$, and large $(\mathrm{dbh}>70 \mathrm{~cm})$. The presence of occupants was recorded by looking up through the basal entrance hole, when possible, by hammering the trunk to provoke the departure of animals, or by observing when animals left the tree at nightfall.

Finally, we fitted two A. derbianus (1 female and 1 male) and one male 1 . macrotis with radio-collars equipped with Biotrack transmitters (a total weight of $7 \mathrm{~g}$ and $1.8 \mathrm{~g}$ respectively). We captured anomalures during the day with nets at the entrance holes of den trees. Animals were followed by radio-tracking from $1800 \mathrm{~h}$ to $0000 \mathrm{~h}$ and from $0000 \mathrm{~h}$ to $0600 \mathrm{~h}$, alternatively. Because they avoided light, even red-filtered, locations were determined from a distance by triangulation. After being equipped, the female A.derbianus was released at its den tree and followed for $114 \mathrm{~h}$ over nineteen half-nights (September, October and December). Locations were recorded every $30 \mathrm{~min}$ and the den tree was localised nearly every day. The adult male $A$. derbianus and the male $I$. macrotis were captured in the same den tree. They were accidentally released about $700 \mathrm{~m}$ away, close to the den tree of the adult female. The I. macrotis was tracked for 48 hours over 8 half-nights (January), and the A.derbianus was tracked for 90 hours over 15 half-nights (January-February).

\section{Data analyses}

Anomalure densities were estimated on the basis of the den tree survey. Factors affecting the selection of den trees were tested to see whether the availability of den trees could regulate population densities. Home ranges were estimated by the convex polygon method (Jenrichs and Turner 1969) using the program Dovidep (R. Quris and V. Biquand, pers. comm.). The cumulative number of quadrats exploited by animals during the radio-tracking periods was calculated using a grid map of the home ranges. Dovidep ivas also used to determine travel distances and activity rhythms using the mean distance travelled per hour.

\section{RESULTS}

\section{Species composition and characteristics of animals}

We identified three species of anomalure in the study area: A. derbianus fraseri Waterhouse, 1842, A. pusillus Thomas, 1887, and 1. m. macrotis Miller, 1898. Body weights and body measurements were taken from both live and dead specimens (Tab. 1).

\section{Population survey in hollow trees and den characteristics}

Spotlighting was not very successful because animals avoided the light. We observed only four Anomalurus and ten Idiurus in over 60 hours of spotlight survey on 15 nights. In addition to this systematic search, opportunistic day and night observations yielded a total of about 20 Anomalurus and 15 Idiurus sightings.

In total, 223 hollow trees $(>30 \mathrm{~cm} \mathrm{dbh})$ were recorded on the 75 ha surveyed area. Fifty-four of these trees were explored for the presence of anomalures. At least 
TABLE 1. - Body weights and body measurements.

\begin{tabular}{|c|c|c|c|c|}
\hline \multirow[t]{2}{*}{ Species } & \multirow[t]{2}{*}{ Age/Sex } & \multirow[t]{2}{*}{$\begin{array}{l}\text { Body weights } \\
\text { (in g) }\end{array}$} & \multicolumn{2}{|c|}{$\begin{array}{l}\text { Body measurements } \\
\quad \text { (in } \mathrm{mm} \text { ) }\end{array}$} \\
\hline & & & Head-body & Tail \\
\hline Idiurus macrotis ${ }^{a}$ & AF & 30 & 86 & 134 \\
\hline Idiurus macrotis $^{b}$ & AM & 26 & 95 & 110 \\
\hline Idiurus macrotis & AM & 23 & 80 & 135 \\
\hline Anomalurus pusillus $^{c}$ & AM & 170 & 200 & 128 \\
\hline Anomalurus derbianus ${ }^{b}$ & AM & 700 & 355 & 290 \\
\hline Anomalurus derbianus ${ }^{b}$ & AF & 740 & 360 & 290 \\
\hline Anomalurus derbianus d & YF & 480 & 300 & 230 \\
\hline
\end{tabular}

AF adult female, AM adult male, YF young female; a female with $3.2 \mathrm{~cm}$ long embryo, found

paralysed in the forest; $\underline{b}$ individuals equipped with a collar-transmitter; $\underline{c}$ individual found dead

after tree falling; $\mathbb{1}_{-}$individual taken dead from eagle' claws.

$24 \%$ (13) were inhabited by anomalures. We found no significant difference in tree diameter between occupied and total explored hollow trees (small, medium, large ; $p>0.2$ ). Among the 13 dens recorded during the surveys, those found opportunistically $(n=5)$, and those observed during the tracking of marked animals $(n=11 ;$ Tab.2 and 3 , a total of 29 dens), a total of 11 tree species were identified (five trees remained unidentified). $P$. bifoliolata, the dominant species in the study area, made up $46 \%$ of the 54 hollow trees examined and $50 \%$ of the trees inhabited by anomalures. Thus, den trees were distributed approximately according to the occurrence of the species, without selection.

Of the 223 hollow trees recorded, $61.5 \%$ had high entrance holes only, $30.5 \%$ had basal holes only (including large openings from the bottom up to $5 \mathrm{~m}$ high in decayed trees), and $8.0 \%$ had both. Half of the explored trees with both basal and high entrance holes were occupied $(5 / 10)$, versus $16.5 \%$ of explored trees with a basal entrance hole only $(6 / 36)$. Finally, two of the 8 trees with high holes explored were occupied. If we consider the dens explored during the surveys, and those found opportunistically $(n=18)$, we observed that most trees $(8 / 10)$ occupied by $A$. derbianus had both basal and high entrance holes. Basal holes had large entrances and could be large empty cavities ; on the contrary, entrance diameters of high holes were generally just large enough to squeeze the body through. All den trees $(n=6)$ used by I. macrotis alone had a large basal entrance hole (Tab. 2). Finally, the two rotten trees occupied by two anomalure species and by a large number of individuals (Tab. 2) had large empty cavities at their base.

Of the 18 den trees, 16 were occupied by a single species $(A$. derbianus, $\mathrm{n}=8$; A. pusillus, $\mathrm{n}=2 ;$ I. macrotis, $\mathrm{n}=6)$; and two by two species including $A$. derbianus and I. macrotis (Tab. 2). A single Anomalurus occupied a den in eight cases $(\mathrm{n}=6$ for 
A. derbianus $; \mathrm{n}=2$ for $A$. pusillus). In three cases, two A. derbianus (a female with a young animal) were found and, in one case, three $A$.derbianus (adult male, another adult and one young) were found in the den (Table 2). Except in one case, I. macrotis nested communally in groups of from a few individuals, to more than 40 . Bats (three different species including Tadarida sp) shared the same den as A.derbianus and/or 1. macrotis in six cases; bats alone were also found in five hollow trees in the surveyed area.

TABLE 2. - Characteristics of den trees and occupant identification.

Number of individuals found at den during hollow tree surveys and opportunistic observations; $\mathrm{Y}=$ young animal. Tree size : $\mathrm{S}=$ small $(30 \mathrm{~cm}<\mathrm{dbh}<50 \mathrm{~cm}), \mathrm{M}=$ medium $(50 \mathrm{~cm}<\mathrm{dbh}<70 \mathrm{~cm})$, $\mathrm{L}=$ large $(\mathrm{dbh}>70 \mathrm{~cm})$. Hole types : $\mathrm{l}=$ basal hole : $2=$ both basal and high hole $; 3=$ high hole.

\begin{tabular}{|c|c|c|c|c|c|}
\hline $\begin{array}{l}\text { Anomalure } \\
\text { Species }\end{array}$ & $\begin{array}{l}\text { Number } \\
\text { of ind. }\end{array}$ & $\begin{array}{l}\text { Tree } \\
\text { size }\end{array}$ & $\begin{array}{l}\text { Hole } \\
\text { type }\end{array}$ & Tree species & $\begin{array}{l}N^{\circ} \text { of } \\
\text { Surveys }\end{array}$ \\
\hline A. derbianus & $\begin{array}{l}1 / 2 \\
(q+Y)\end{array}$ & $\bar{L}$ & 2 & $\begin{array}{l}\text { Paraberlinia } \\
\text { bifoliolata }\end{array}$ & 2 \\
\hline id. & 1 & $S$ & 1 & & 1 \\
\hline id. & $\begin{array}{l}2 \\
(q+Y)\end{array}$ & L & 1 & $\begin{array}{l}\text { Scyphocephalium } \\
\text { ochocoa }\end{array}$ & 1 \\
\hline id. & 1 & $M$ & 2 & id & 1 \\
\hline id. & 1 & $\mathbf{M}$ & 3 & & 1 \\
\hline id. & 1 & $\mathbf{M}$ & 2 & $?$ & 1 \\
\hline id. & 1 & $M$ & 2 & $?$ & 1 \\
\hline id. & 1 & $\mathrm{~L}$ & 2 & $?$ & 1 \\
\hline A.pusillus & $1 / 1$ & $M$ & 3 & Irvingia & 2 \\
\hline id. & 1 & L & 2 & $\frac{\text { Desbordesia }}{\text { glaucescens }}$ & 1 \\
\hline I.macrotis & $+21+4$ & L & 1 & & 2 \\
\hline id & $1 / 1$ & $\mathbf{M}$ & 1 & $\begin{array}{l}\text { Gilletiodendron } \\
\text { pierreanum }\end{array}$ & 2 \\
\hline id & +2 & $S$ & 1 & $\begin{array}{l}\text { Irvingia } \\
\text { gabonensis }\end{array}$ & 1 \\
\hline id & $3 /+4$ & L & 1 & $\frac{\text { Paraberlinia }}{\text { bifoliolata }}$ & 2 \\
\hline id & $+5 /+10$ & $\mathrm{~L}$ & 1 & 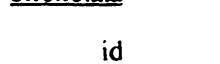 & 2 \\
\hline id & +5 & L & 1 & id. & 1 \\
\hline $\begin{array}{l}\text { A.derb ianus } \\
+ \\
\text { I.macrotis }\end{array}$ & $\begin{array}{l}2(Q+Y) \\
+5 /+40\end{array}$ & L & 2 & $\frac{\text { Klainedoxa }}{\text { gabonensis }}$ & 2 \\
\hline $\begin{array}{l}\text { A.derbianus } \\
+ \text { I.macrotis }\end{array}$ & $\begin{array}{l}3\left(\sigma^{\top}+Y\right) \\
+20\end{array}$ & L & 2 & $\begin{array}{l}\text { Pterocarpus } \\
\text { soyauxii }\end{array}$ & 1 \\
\hline
\end{tabular}




\section{Estimates of population densities and biomasses}

Comparison of the two 75 ha surveys shows that at least $70 \%$ of den trees were used by the same species during both study periods ; this suggests some fidelity to the den. This was confirmed by the marked female A.derbianus, which used the same den for at least four months (see below), while 4-5 I. macrotis were noted at the same den for at least three years (J.-P. Gautier, pers. comm.). This den fidelity allows us to estimate population densities, from the minimum and maximum numbers of individuals found in the two surveys.

If the 54 trees checked for the presence of anomalures (out of the 223 hollow trees found over $75 \mathrm{ha}$ ) were a representative sample, the density of occupied dens can be estimated at 71 per square kilometer. Thus, densities of anomalures can be extrapolated to about 27-54 A. derbianus, 5 A. pusillus and 164-437 Idiurus per square kilometer (Tab. 4), or a biomass of about 30 to $65 \mathrm{~kg} / \mathrm{km}^{2}$, including 20 to $40 \mathrm{~kg}$ for the genus Anomalurus.

\section{Use of time and space by A. derbianus and I. macrotis}

A. DERBIANUS - A. derbianus (including the marked animals) began activity between $18.10 \mathrm{~h}$ and $18.55 \mathrm{~h}(\mathrm{n}=27)$, with most observations $(60 \%)$ of the beginning of activity occurring between $18.30 \mathrm{~h}$ and $18.45 \mathrm{~h}$, when the light level in the forest became very low. Animals ended activity and entered the den from $05.20 \mathrm{~h}$ to $06.20 \mathrm{~h}$ $(\mathrm{n}=14)$, with a maximum $(57 \%)$ between $05.45 \mathrm{~h}$ and $06.15 \mathrm{~h}$, at sunrise.

The distances travelled during one night (calculated from 30' interval locations; $\mathrm{n}=114 \mathrm{~h}$ of radio-tracking) averaged $540 \mathrm{~m}$ for the female $A$. derbianus. Travels alternated between local movements in a small area and rapid movements over distances up to $100 \mathrm{~m}$. However, mean distances travelled per hour did not show marked activity rhythms. The total surface area used by the female was 3.37 ha (Fig. 1). By the end of October, the cumulative number of quadrats she used had reached a plateau. Space exploitation analysis indicated a small central area $(0.38 \mathrm{ha}, 11.3 \%$ of the home range $)$ with $50 \%$ probability to find the animal. The female used six den trees (Fig.1). A main den was used in $79.5 \%$ of cases $(n=44 ;$ tab. 3$)$. This primary den tree was a large $P$. bifoliolata, hollow from the base to at least $20 \mathrm{~m}$ high, with a large opening at the bottom and a small hole at $15 \mathrm{~m}$ high. The other dens were only used once or twice, after stressful experiences at the preferred den tree (see below). These secondary den trees had only high entrance holes.

The mean distance travelled during the night by the translocated adult male was $1060 \mathrm{~m}$. This male first explored an area of $9.25 \mathrm{ha}(\mathrm{n}=90 \mathrm{~h})$. This surface area decreased and stabilized around 3.3 ha during the last eight days of the study, when the male appeared to establish his new home range (Fig. 1). The male used five den trees $(n=18$; Tab. 3), and at the end of the study, he started to use a Santiria trimera tree as a primary den.

I. MACROTIS - During the $48 \mathrm{~h}$ duration of radio-tracking, the translocated male I. macrotis used an area of three hectares with a mean distance travelled averaging $790 \mathrm{~m}$ (Fig. 1). Its activity period was very similar to that of A. derbianus, beginning between 18.15 and $19.00 \mathrm{~h}$ and ending about 06.00 . Only one den tree, a large P. bifoliolata, was identified (Tab. 3). 


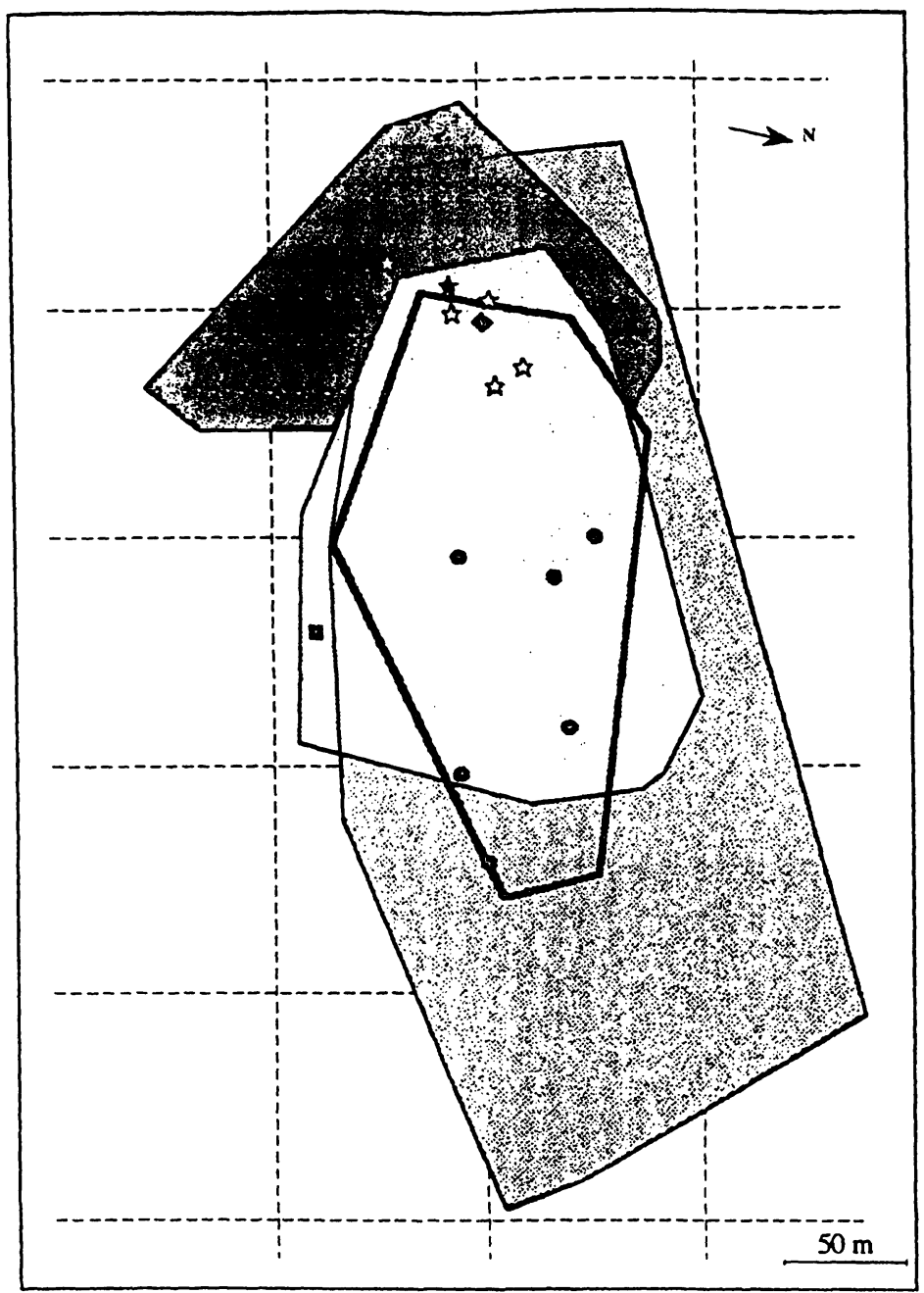

$\star$ primary den trec of the femalc $A$. derbianus

sf other den trees of the female A. derbianus

- den trees of the male A. derbianus

- den tree of the male I. macrotis

- location where the A. derbianus and $I$.

macrotis males were released home range of the female A. derbianus

‥ area cxplored by the male A. derbianus

area explored by the male $I$. macrotis

new home range of the male $A$. derbianus between the 08.02 .96 and the 26.02 .96

pathways

Fig. 1. - Home ranges and den trees of the three anomalures followed by radio-tracking. 
TABLE 3. - Identification and description of the hollow trees used as dens by the anomalures followed by radiotracking. $\mathrm{N}$ : number of uses as den tree. See Table 2, for tree sizes and hole types categories.

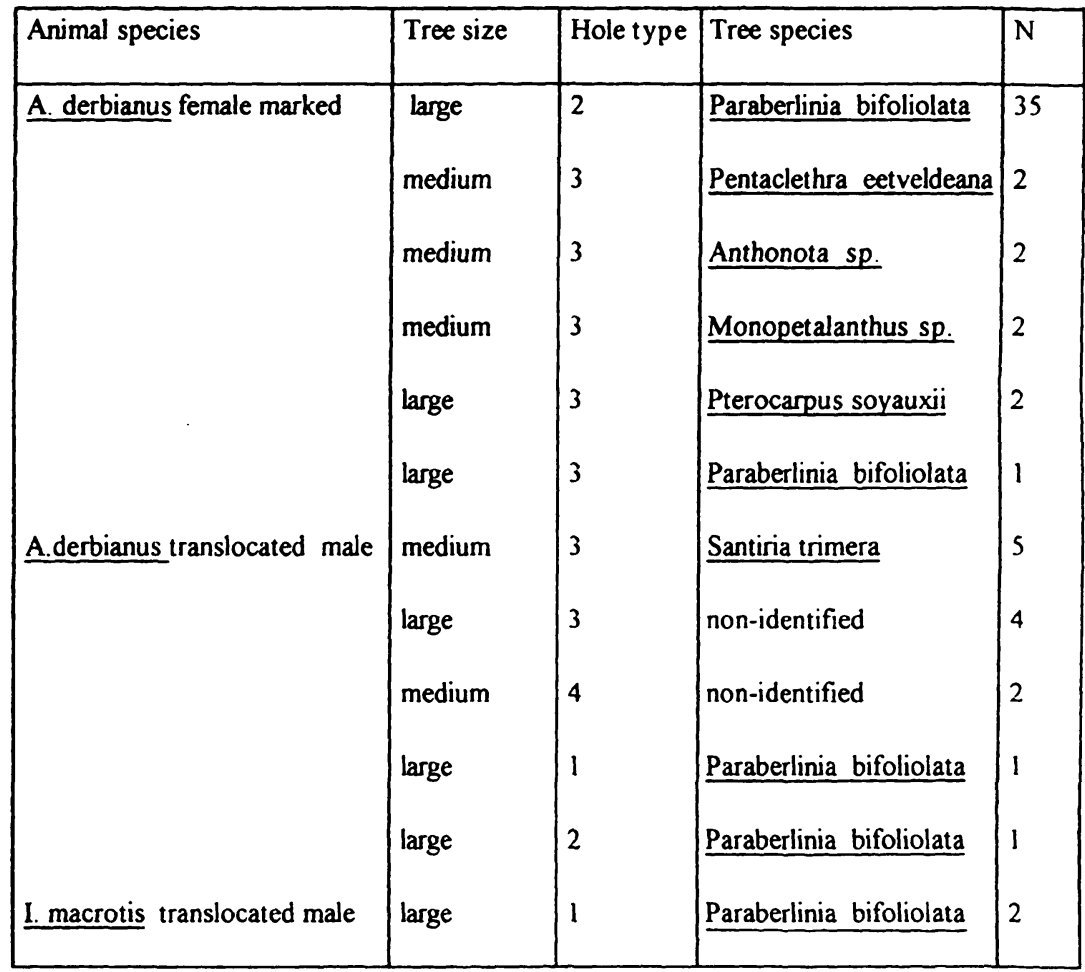

\section{Behaviour}

At the den, A. derbianus were usually found alone (see above). When leaving or entering their dens, animals usually used the higher hole. However, the marked female and its young exited by the lower hole when a Poiana richardsoni (Viverridae) entered the den by the higher hole. Similarly, the marked male was captured at the bottom hole after he was disturbed when a net was installed over the higher hole. Except in three cases when the young left the den behind its marked mother, only one individual left the den at a time. Before leaving the den, animals frequently sat at the entrance and surveyed the surroundings. Before entering the den, they could remain up to 30 minutes on the trunk of the tree, close to the hole.

Most direct observations of active A. derbianus outside their dens were of gliding animals or animals climbing up tree trunks before gliding again. They were generally alone, but two $A$. derbianus were observed on several occasions, either staying close to a den, leaving the den one behind the other (including the marked female and the young), feeding close together on the same trunk, or gliding one after the other. Once, three $A$. derbianus glided several times from tree to tree, chasing each other gently as if they were playing. 
Seven observed feeding bouts of $A$. derbianus included scratching bark with teeth of Brachystegia durandii ( $\mathrm{n}=3$ cases), $P$. bifoliolata $(\mathrm{n}=1)$ and Dialium pachyphyllum $(n=3)$, all Caesalpiniaceae species. Anomalures did not eat the bark; they cut it open, let the debris fall to the ground, and licked the exuding material ; only the phloem sap was therefore ingested. The stomach content of a subadult animal killed by an eagle consisted mostly of leaves and petioles, a few fragments of bark, over 100 ant heads belonging to at least three species and about 40 termite heads (mainly soldiers). The content weighed $60 \mathrm{~g}$ (about $13 \%$ of the body weight of the animal).

I. macrotis were always found in groups at den trees except once. All individuals left their den using the upper part of the bottom entrance hole, in a single file $(n=7$ observations) ; then, in contrast to A. derbianus, they usually stayed some time on the den tree (up to at least $30 \mathrm{~min}$ ), moving up and down the trunk before gliding independently to neighbouring trees. During the activity period, I. macrotis were always solitary, except in one case when two individuals were seen close from each other on a tree trunk. They were observed three times gnawing the bark of $P$. bifoliolata.

\section{DISCUSSION}

The community of anomalures of the Forêt des Abeilles includes at least three species : two species of Anomalurus (A. derbianus and $A$. pusillus) and one species of Idiurus (I.macrotis). Body weights and measurements of $A$. derbianus and I. macrotis specimens are in accordance with the few data points previously obtained (Rahm 1966 ; Rosevear 1969). No A. pusillus body weights were found in the literature.

The presence of $A$. beecrofti known to occur on the right bank of the Oggoué River (eg. Rio Muni; Jones 1971 and N-E Gabon ; Emmons et al. 1983), was not confirmed on our study area (left bank of the Ogooué River). The species has often been described as diurnal (Kingdon 1974) and it has been observed crouching flat against a trunck outside during the day (Rosevear 1969). At La Makandé, diurnal observations of large anomalures have been made on several occasions suggesting that $A$. beecroftii could be present. However, diurnal observations could correspond to individuals disturbed at their sleeping sites. At Makokou, A. beecrofti were observed to glide and to feed at night (L. Emmons, pers. comm.).

The possible absence of I. zenkeri at the Forêt des Abeilles is not surprising. Indeed, no specimen seems to have been collected in Central and South Gabon, and its southern limit of distribution is said to be South Cameroon and Northern Gabon (Malbrant and Maclatchy 1949 ; Rosevear 1969). Finally, we found no evidence of the presence of $Z$. insignis, a very rare species whose distribution is poorly known (Dieterlen 1993): it was identified in N-E Gabon (P. Charles-Dominique, G. Dubost and L. Emmons, pers. comm.) where L. Emmons saw an individual feeding twice on termites on the side of a tree.

Density estimates obtained for the three nocturnal species at La Makandé appear unexpectedly high for animals which are considered rare. In the absence of other density estimates, comparison can be made with other gliders (flying phalangers, Marsupiala, Phalangeridae) from Australasia. The small sugar glider (Petaurus breviceps), which lives in large groups, like the small 1 . macrotis, reaches a similar density of 220 to 610 individuals $/ \mathrm{km}^{2}$ (Henry and Suckling 1984). The greater Petauroides volans (1265 to $1490 \mathrm{~g}$ body weight, i.e. much heavier than A. derbianus) has a lower density 
around 5.6 to 8 individuals $/ \mathrm{km}^{2}$. However, it reaches a higher biomass than $A$. derbianus $\left(71 \mathrm{~kg}\right.$ versus $\left.40 \mathrm{~kg} / \mathrm{km}^{2}\right)$.

As suggested by Rahm $(1966,1969)$ for A. jacksoni, the species of tree used for shelter seems unimportant for anomalures, although some tree species, like $P$. bifoliolata at La Makandé, are more prone to rotten or hollow cores, or to deep fissures and cavities. Anomalures mainly select den trees on the basis of the quality of entrance holes. I. macrotis select trees with large entrance holes at the bottom, while A. derbianus preferentially choose trees with both basal and high holes, while trees with only high holes are used as secondary den trees. Similarly, in Rio Muni, trees used as dens by $A$. derbianus had hollows open at the top and the bottom (Jones 1971). The predation attempt by Poiana on A. derbianus showed the importance of two entrances to escape predators. Because, at La Makande site, a lot of trees corresponding to these characteristics were found unoccupied, we conclude that den availability is not a factor limiting population density. Nonetheless, as noted by Rahm (1966), larger colonies of anomalures, including several species, occurred in very large hollow trees that were "virtually empty shells".

Gliders of Australasia and flying squirrels (Rodentia, Sciuridae) of Eurasia, also den in hollow trees, and Kehl and Borsboom (1984) noted that the greater glider was generally faithful to one or two primary dens. Most dens had multiple entrances, but neither tree species nor type of cavity (trunk or limb) influenced the selection of primary dens. Like gliders, anomalures seem to be attached to one primary den tree. Den fidelity was also observed for A. jacksoni (Rahm 1969).

The nycthemeral activity rhythm of anomalures was previously described only from occasional sightings or by the observation of captive animals (Rahm 1966 ; Jones 1971 ; Kingdon 1974). Our study confirms that A.derbianus and I. macrotis have exclusively nocturnal activity with a very regular activity cycle. However, during the night activity period, there was no clear pattern of activity, unlike some other nocturnal species which exhibit two peaks of activity, at the beginning and at the end of the night (such as prosimians; Charles-Dominique 1972).

Our data on space use are preliminary because they derive from few individuals of which two were translocated. Results gained from these individuals should be cautiously taken. Differences in home range sizes between the male and female A. derbianus could result from sex or individual differences as well as from the translocation of the male, which displayed an erratic behaviour. However, after one month, the home range sizes of the two animals were very similar. In Australian greater gliders (Petaltroides volans), Kehl and Borsboom (1984) noted that there was no significant difference in home range surface area between adult males and adult females (2.5 and 2.6 ha on average respectively); however males spent twice as much time moving as females. Similarly, the mean distance covered by the male A.derbianus was twice as long as that covered by the female.

The distance covered by the male I. macrotis is quite remarkable given its small body size in relation to Anomalurus and could correspond to an erratic phase caused by translocation. However, Durrell (cited by Kingdon 1974) suggested that Idiurus could travel four miles in one night. Such distances are higher than those covered by sugar gliders, which live on home ranges of less than one hectare (Henry and Suckling 1984).

Records of the feeding behaviour of anomalures are rare and most were recorded close to villages, where anomalures eat oil palm nuts, and petals of roses and hisbicus (Kingdon 1974). However, all authors pointed out the fact that anomalures eat bark and leaves (eg. Rahm and Christiansen 1963). From stomach contents examination, Emmons et al. (1983) concluded that A. derbianus was mainly folivorous and Idiurus 
sp. mainly frugivorous. Our direct feeding observations involved bark peeling and ingestion of phloem sap. Similar feeding behaviour has been observed for the yellowbellied and sugar gliders on eucalypt in Australia (Henry and Craig 1984 ; Henry and Suckling 1984). P. volans eats bark and invertebrates under bark, as well as honeydew excreted by insects visiting sap site. At La Makandé, we observed that sap flow sites were also used by insects and could be revisited by anomalures to eat honeydew and/or insects. However, the great amount of insects found in the stomach of A.derbianus suggests that insects were probably actively hunted and not just eaten opportunistically.

Communal nesting is characteristic of small anomalures, including both I. macrotis and I. zenkeri (this study and Rahm 1966, 1969). Such communal nesting is also frequent in some flying squirrels such as Glaucomys volans (Layne and Raymond 1994) and small gliders like Petaurus australis (Russell 1984). In contrast, Kehl and Borsboom (1984) noted that the sharing of dens by greater gliders occurred only in two situations : between adults during the mating period, and between females and suspected young.

We never observed more than two or three A.derbianus sharing the same den tree, and each time one of them was a young. Similarly, in Rio Muni, the number of A. derbianus found in hollow trees varied from one to three individuals $(n=5$ observations: Jones 1971) and Rahm (1960) noted that A. jacksoni lived alone or in pairs. More data are required on males to tell how they associate with females and whether A. derbianus are basically solitary animals with females and young association or live in family groups like the greater glider ( $P$. volans).

Very few data were previously reported about $A$. pusillus. Our study provides the first published data on body weight, confirms the relative scarcity of the species and the use of hollow trees as den, and suggests that individuals tend to den alone. In one occasion, Rahm (1969) observed A. jacksoni and A. pusillus at the same den.

Our results, compared with those obtained from long term studies on gliders in Australasia (Smith and Hume 1984) suggest a striking convergence between African flying squirrels and flying phalangers, especially between species with similar body weights.

\section{ACKNOWLEDGEMENTS}

This study was supported by the program BIOFAC (DGVIII ; EU). We would like to thank J.-P. Gautier for his helpful advice in the field, A. Moungazi and F. Vooren for tree species identification, and R. Vercauteren who collected the anomalure killed by the eagle. Thanks are also due to V. Biquand who spent time on the Dovidep program (Dovidep, Station Biologique de Paimpont - France), M. Colyn who examined the skulls of our specimens to confirm their identity, L. Emmons, A. Cockle, and E.J. Heske for helpful critical comments and/or for English revision.

\section{BIBLIOGRAPHY}

Charles-Dominique, P., 1972. - Ecologie et vie sociale de Galago demidovii (Fischer 1808; Prosimii). Pp. 7-41, in: Behaviour and ecology of nocturnal prosimians (P. CharlesDominique and R.D. Martin, eds.). Verlag Paul Parey, Berlin, 89 pp. 
Dieterlen, F., 1993. - Family Anomaluridae, pp. 757-758; in : Mammal species of the world. A taxonomic and geographic reference, 2nd ed. (D.E. Wilson and D.M. Reeder. 1993) Smithsonian Institution Press, Washington and London, $1206 \mathrm{pp}$

DoucET, J.-L., 1996. - Régénération naturelle dans la Forêt des Abeilles (Gabon). Unpublished report, University of Agronomic Sciences, Gembloux, Belgium, $127 \mathrm{pp}$.

Emmons, L.H., A. Gautier-Hion and G. Dubost, 1983. - Community structure of the frugivorous-folivorous forest mammals of Gabon. J. Zool. Lond., 199 : 209-222.

HeNRY, S.R. and S.A. CRaIG, 1984.- - Diet, ranging behaviour and social organization of the yellow-bellied glider (Petaurus australis Shaw) in Victoria. Pp. 331-341 ; in : Possums and Gliders (A. Smith and I. Hume, eds.). Surrey Beatty and Sons, Norton, Australia, $598 \mathrm{pp}$.

HenRY, S.R. and G.C. SuCKLING, 1984. - A review of the ecology of the sugar glider. Pp. 354358 ; in: Possums and Gliders (A. Smith and I. Hume, eds.). Surrey Beatty and Sons, Norton, Australia, $598 \mathrm{pp}$.

JENRICHS, R.I. and F.B. TURNER, 1969. - Measurement of non-circular home range. Journal of Theoretical Biology, 22 : 227-237.

JONES, C., 1971.- Notes on the anomalurids of Rio Muni and adjacent areas. Journal of Mamma$\log y, 52: 568-572$.

KeHL, J. and A. BORSBOOM, 1984. - Home range, den tree use and activity patterns in the greater glider. Pp. 229-236; in : Possums and Gliders (A. Smith and I. Hume, eds.). Surrey Beatty and Sons, Norton, Australia, $598 \mathrm{pp}$.

KINGDON, J., 1974. - East African Mammals : An atlas of Evolution in Africa. Volume II, Part B (Hares and Rodents). Academic Press, London, 704 pp.

LASSERE, F. and A. GAUTIER-Hion, 1995. - Impacts environnementaux d'une exploitation sélective en forêt tropicale : l'okoumé en Forêt des Abeilles - Gabon. Unpublished Report. $29 \mathrm{pp}$.

LAYNE, J.N. and M.A.V. RAYMOND, 1994. - Communal nesting of southern flying squirrel in Florida. Journal of Mammalogy, 75 : 110-120.

Malbrant, R. and A. McLatchy, 1949. - Faune de l'équateur français africain. T2 : Mammifères. Paul Lechevalier ed., Paris. 323 pp.

RAHM, U., 1960. - L'Anomalurus jacksoni de Winton. Bulletin de la Société Royale de Zoologie d'Anvers, $\mathrm{n}^{\circ} 18,16 \mathrm{pp}$.

RaHM, U., 1966. - Les mammiferes de la forêt équatoriale de l'Est du Congo. Annales du Musée Royal de l'Afrique Centrale (Tervuren, Belgique), Série in $-8^{\circ}$ (Sciences Zoologiques), $\mathrm{n}^{\circ} 149,121 \mathrm{pp}$.

RAHM, U., 1969. - Dokumente über Anomalurus und Idiurus des östlichen Kongo. Zeitschrift für Säugetierkunde, 34 : 75-84.

RAHM, U., and A. Christiansen, 1963. - Les mammifères de la région occidentale du lac Kivu. Musée Royal de l'Afrique Centrale - Tervuren, Annales, Série in- $8^{\circ}$ - Sciences Biologiques, $\mathrm{n}^{\circ} 118,83 \mathrm{pp}$.

Rosevear, D.R., 1969. - The rodents of West Africa. Trustees of the British Museum (Natural History), London, 604 pp.

RUSSEll, R., 1984. - Social behaviour of the yellow-bellied glider, Petaurus australis reginae, in North Queesland. Pp. 343-353 ; Possums and Gliders (A. Smith and I. Hume, eds.). Surrey Beatty and Sons, Norton, Australia.

SMITH, A. and I. Hume, 1984. - Possums and Gliders. Surrey Beatty and sons, Norton, Australia, $598 \mathrm{pp}$. 

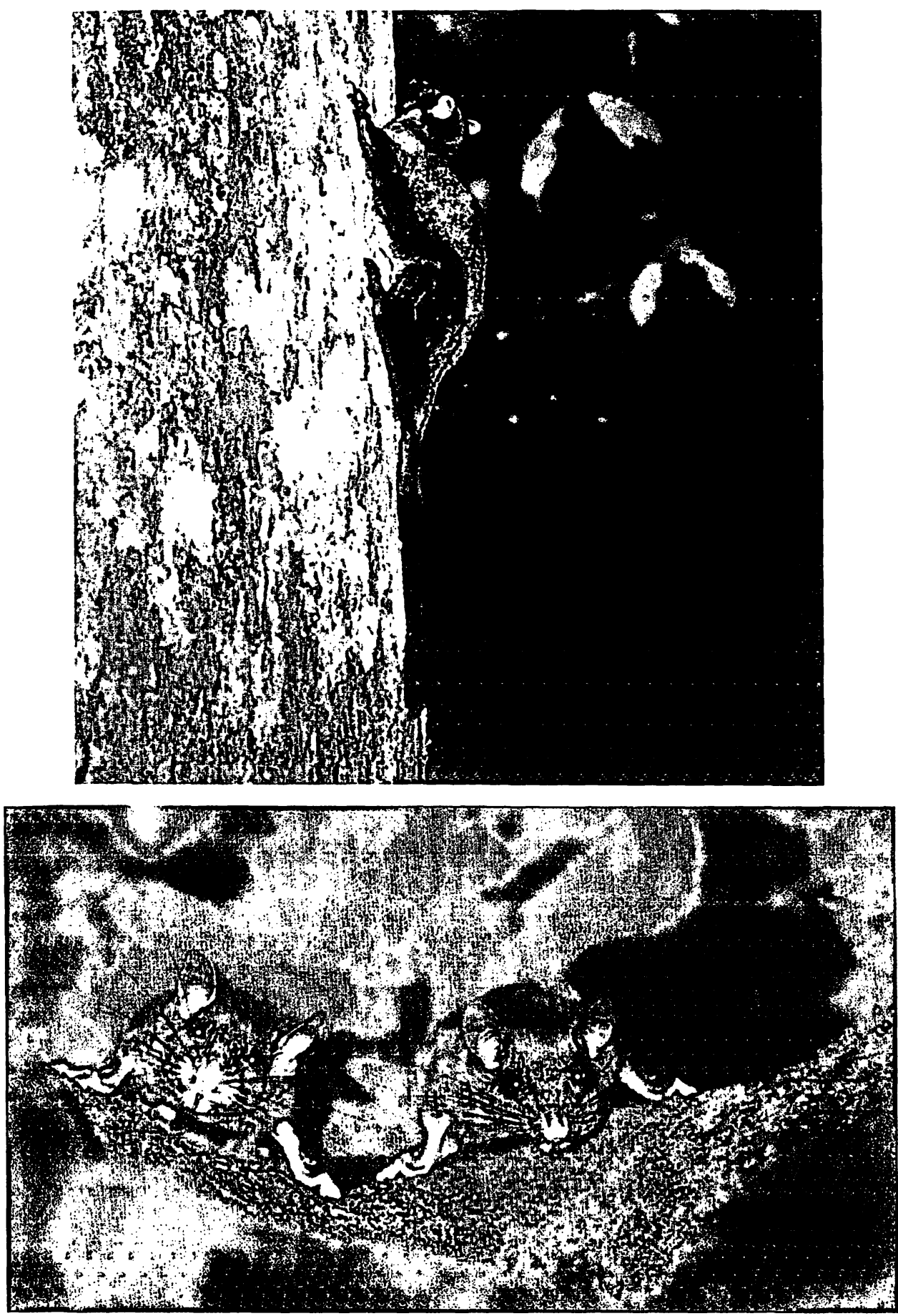

P'lanche 1. - En haut: "Anomalurus derbianus regagnant son gîte, à $15 \mathrm{~m}$ de hauteur ».

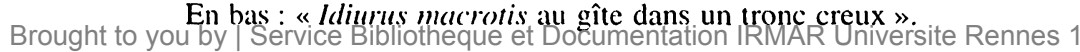


Brought to you by | Service Bibliotheque et Documentation IRMAR Universite Rennes 1 Authenticated Download Date | 11/23/17 3:53 PM 